\title{
Geospatial Assessment for Sustainable Management of Mangroves in Kilifi Creek, Kenya
}

\author{
Mark Kipkurwa Boitt, Amina Omar Said \\ Department of Geomatic Engineering and GIS, Jomo Kenyatta University of Agriculture and Technology, Nairobi, Kenya \\ Email: mboitt@jkuat.ac.ke, am.omarsaid@gmail.com
}

How to cite this paper: Boitt, M. K., \& Said, A. O. (2019). Geospatial Assessment for Sustainable Management of Mangroves in Kilifi Creek, Kenya. Journal of Geoscience and Environment Protection, 7, 1-13. https://doi.org/10.4236/gep.2019.77001

Received: February 2, 2018

Accepted: July 15, 2019

Published: July 18, 2019

Copyright (อ 2019 by author(s) and Scientific Research Publishing Inc. This work is licensed under the Creative Commons Attribution International License (CC BY 4.0).

http://creativecommons.org/licenses/by/4.0/ (c) (i) Open Access

\begin{abstract}
Mangroves are salt-tolerable trees that grow on zones parallel to the coastline along the creeks. They follow the mud flat accretions which are unvegetated areas consisting of sand or gravel that are either exposed or flooded by tides. They provide $70 \%$ of the wood requirement along the Kenyan Coast. Currently, there are no harvest plans of the mangroves and there is selective removal of suitable poles and most of the quality poles have been wiped out. This not only leaves the inferior species unsuitable for the market but also affects the quality of the forest. Moreover, areas that are suitable for mangroves growth have been occupied by human settlement and infrastructure, hence, there is a need of sustainable use of the mangroves so as to protect them from degradating and eventually extinction. To achieve this, geospatial techniques need to be employed in order to determine the spatial extent of the vegetation and devise methods and plans of managing them. The Kilifi Mangrove Forest creek is home to major six species: Avicennia marina, Ceriops tagal, Sonneratia alba J., Rhizophora mucronata, Lumnitzera racemosa and Bruguiera gymnorrhiza. This study showed that the most dominant species in the forest is $A v i$ cenna Marina which had a percentage stand of $25.6 \%$. The less dominant species Lumnitzera racemosa and Heritiera littoralis had a stand of $0.10 \%$ which were restricted for harvesting in the analysis, they need to be protected so as to prevent its extinction in the forest which will affect the biodiversity and richness of the forest. Density and heights of the mangroves were considered so as to decide on which areas to do reforestation in order to protect the forest and help in preventing soil erosion. The final suitable area for harvesting after carrying out conditional and majority filter was 394 acres which are $9 \%$ of the total forest area. The total area most suitable for reforestation is 1151 acres which are $27 \%$ of the total Kilifi Mangrove Forest. A recommendation for proper harvesting plans should be made by identifying suitable sites for
\end{abstract}


harvesting and areas which showed low mangrove stand density should be identified and necessary measures should be taken to restore them.

\section{Keywords}

Environmental Protection, Natural Resource Management, Mangroves, Suitability Analysis

\section{Introduction}

\subsection{GIS and Forestry}

The use of geospatial technologies is being embraced globally in monitoring and managing of the various forest activities. The GIS software has been used to improve the management of forests as compared to the old techniques. The geospatial technology is able to provide the information about the spatial distribution of the forest inventory attributes, being able to query it, carry out various analyses, carry out various simulations and modelling and provide with the best sites for various activities such as harvesting, reforestation, etc. Geospatial technology helps in ensuring that there is sustainable utilization of the forest resources to prevent degradation of the forest ecology. Accessing the feasibility of these multiple uses is greatly enhanced by the use of GIS techniques (Gupta et al., 2012). In a research work that was carried out in Australia to study the various applications of GIS in community-based forest management in Australia (Baral, 2004), it showed that GIS can help foresters and community-based organizations to meet the challenges of integrating biophysical, socio-economic and cultural information for community forest management. This will encourage the community to participate in the gathering of the forest data which will assist in the forest management. GIS can also be a crucial tool for linking restrictions in timber management practices for the preservations of biodiversity and practical sustainable forest management (Baral, 2004).

\subsection{GIS and Forest Harvesting}

Herrington and Koten (1988) assert that planning of the forest harvesting needs information of the individual compartments and the geographic relationship between the compartments. The harvest model used a raster GIS for creating a map showing the market value of the standing timber. The costs were calculated from the forest type, soil classification, roads, management compartments, streams and topography. The model assumed there were no costs on the loading of logs onto the trucks and the probation of skidding on the streams and lakes.

Moore and Lockwood (1990) developed a forest harvest planning system known as Harvest Schedule Generator (HSG) Wood Supply Model which incorporates GIS to help in the designing and evaluation of the long-term timber harvest schedules. The basic GIS layer is the forest inventory, each stand as- 
signed an attribute of the year of stand, productivity of the site, area, sylvicultural treatment class and relative stocking factor. The HSG model shows the potential utility of the simulation model in GIS. GIS was used for the database management and the spatial representation of the output after running the model.

Baskent and Jordan (1996) described a spatial wood supply simulations model known as GISFORMAN. The model was connected to a GIS database. The model could forecast in selected interval of years. The management strategies were very specific mapped schedules. This ensured that sustainable use of the forest resources.

GIS can be utilized to optimize timber harvesting (Pecora et al., 2014). The study concluded that preliminary spatial analysis could be utilized by forest companies to improve the mechanization of forest harvesting. The forest companies will be able to design suitable systems in relation to the different territorial conditions of the forest by using the GIS tools. This will lead to optimization of the woodcutter work.

Decision support system called Optimal was used in Czech Republic (Marušák el al., 2015) in which GIS was used as a tool for spatial and temporal decision making for harvest scheduling. Optimal allowed the editing of the harvest units, which were a restriction of the forestry act and/or forest managers' requirements. It allowed creating and checking strict spatial limits of harvest units. It could show alternative harvest scheduling while taking into account the various constraints. The forest manager could create various scenarios within a short time to find the best solution.

\subsection{Restored Mangroves Studies}

In a review of functionality of restored mangroves (Bosire et al., 2008) showed that reforested plots have a potential of yielding 4863 stems per hectare for Rhizophora mucronata plantation which is much higher than the stem density in natural stand of the same density at the same site which was found to have stem density of 1796 stems per hectare. In a study carried in Gazi Bay (Bosire et al., 2003) to assess the possibility of natural colonization within the restored mangroves stands showed that mangrove reforestation facilitated natural colonization of the sites. The study suggested that clear felling of mangroves greatly impaired the natural regeneration mainly due to the unfavorable site conditions. The regeneration status of the mangrove forest in Mida creek was studied (Kairo et al., 2002) showed that the standing densities of the forest were high considering that the mangroves of Mida were not pristine. The regeneration values gotten from Mida Creek, showed that if the objectives for the Mangroves in Mida Creek to have a dense forest cover $(\geq 60 \%)$ irrespective of species, then there is no need of replanting degraded mangroves since the Mida's mangroves can recover itself. The major outcome of the study was that the exploited mangroves do not necessarily disappear but change qualitatively. It leads to a shift in the dominant species on the ecological function. 


\subsection{Study Area}

Kilifi Creek is located in Kilifi County, $55 \mathrm{~km}$ north of Mombasa City, Kenya and approximately $35 \mathrm{~km}$ south of Malindi Town. The creek has an estimated area of 600 ha, with a narrow opening towards the ocean and occupies $22.4 \mathrm{~km}^{2}$ (Sigana et al., 2009). It has a temperature range of $24^{\circ} \mathrm{C}$ to $28^{\circ} \mathrm{C}$. The deepest part of the creek is approximately $38 \mathrm{~m}$ wide at the entrance and a distance of about $4 \mathrm{~km}$ (500 $\mathrm{m}$ wide) separates the ocean from the open lagoon locally known as the Bahari ya Wali. The Western side of the creek is extensively covered with mangrove trees of various species covering an area of approximately 360 ha. There are two main water channels Ndzovuni and Rare winding in between the mangrove forest to form the Konjora which leads into Bahari ya Wali. The mangroves of Kilifi Creek are naturally separated into two main tidal creeks, Kibokoni and Maya respectively. Kilifi Mangrove Forest was selected to be the study area because it has not been getting much attention in terms of research studies as compared to other Mangrove forests in Kenya (Figure 1).

\section{Materials and Methods}

The study was done using forest inventory and DEM. The data collected was cleaned and necessary readjustments made. Suitability analysis was then carried out. The various data used are summarized below in Table 1 .

\subsection{Data Pre-Processing}

For the data to be used in the analysis, several data processing techniques were used. The data processing techniques used included: clipping to extract datasets that fall within the study area, reprojection to transform the different coordinate

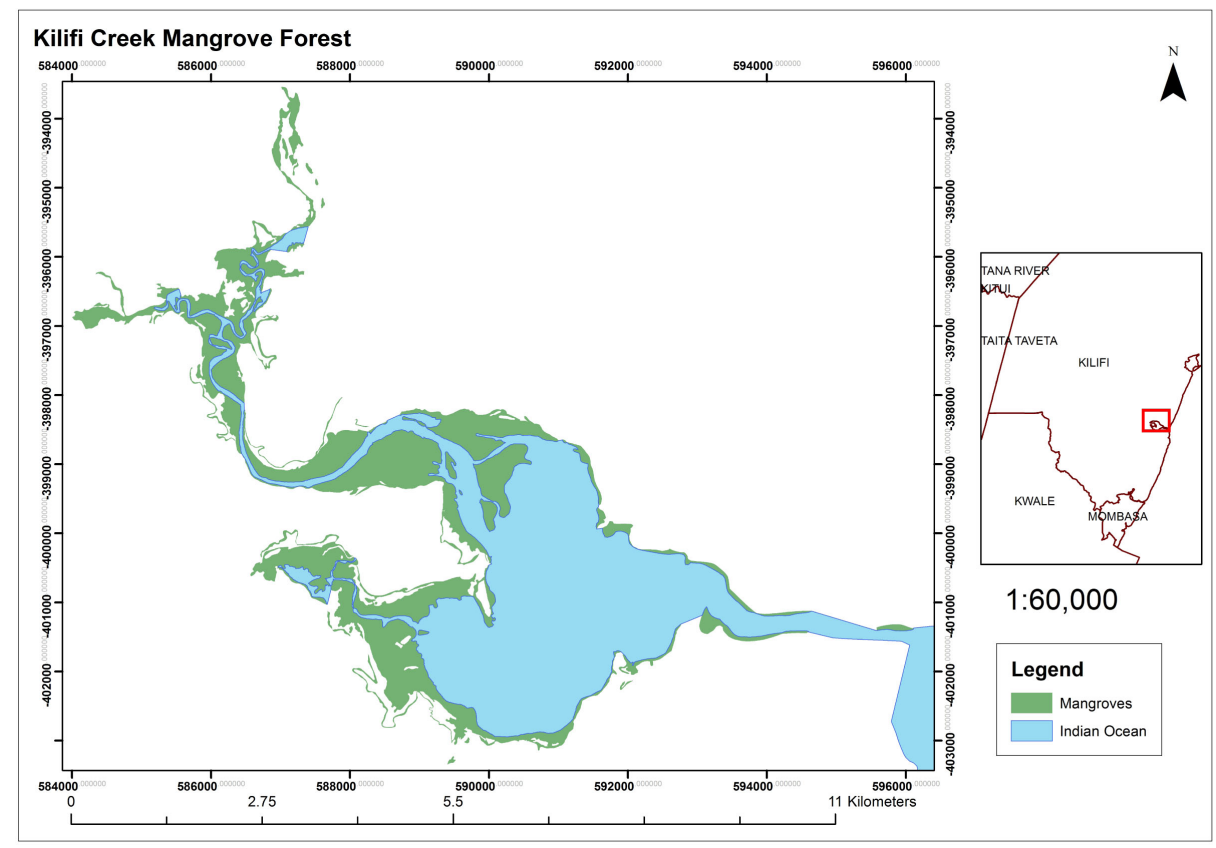

Figure 1. Kilifi creek showing mangroves. 
Table 1. Data sets.

\begin{tabular}{ccc}
\hline & Data & Source \\
\hline 1 & Forest Inventory & KMFRI, Kenya \\
2 & Satellite imagery & USGS websites \\
3 & DEM & USGS websites \\
4 & Roads & ILRI, Kenya \\
\hline
\end{tabular}

systems to one common coordinate system, spatial adjustment of the data, conversions from polygon-raster and vice versa, reclassification, buffering and erase.

\subsection{Weighting and Weighted Overlay Analysis}

Questionnaires were distributed to the forestry experts and forest users in order to determine the weights of the various factors. The weighting technique used was pairwise comparison of Analytical Hierarchy Process (AHP). The different group of people which was targeted had different opinions or preferences of the factors to be considered. Four variables/factors were considered for the harvest zones and three for the regeneration zones. The variables were used for pairwise comparison and in turn the weights for the variables were calculated. Weighted overlay analysis is the combination of different layers with different weights of the same geographic location into one single layer which gives a suitability map. The weighted overlay too works by multiplying the cell values of each raster variable by its weight and adding the product together in order to give the resulting raster output.

Weighted overlay was carried out after assigning weights to the variables. The weighted overlay analysis was carried out using the weighted overlay tool found in ArcGIS in order to generate suitability map for the harvest zones and the regeneration zone, each based on its variables (Figure 2).

\subsection{Accessibility Routes Extension}

Routes extension was carried out using the Cost Distance tool and the Cost Path tool. The two tools assist in determining the least cost path from the source to the destination (Figure 3).

\section{Results and Discussion}

\subsection{Slope}

The slope in Kilifi Creek ranges from $0 \%$ to $48.5 \%$, areas with green have highest slope value areas, and orange-yellow the moderate slope values and the red are the relatively flat areas. Forest harvesting is preferred to be carried out in relatively flat areas so as to prevent the occurrence of erosion. Planting of trees is preferable on areas which are relatively flat. The slope generated from a $30 \mathrm{~m}$ Aster DEM was reclassified into 10 classes of equal range. Figure 4 shows the sloppiness of the area around the Kilifi creek. 


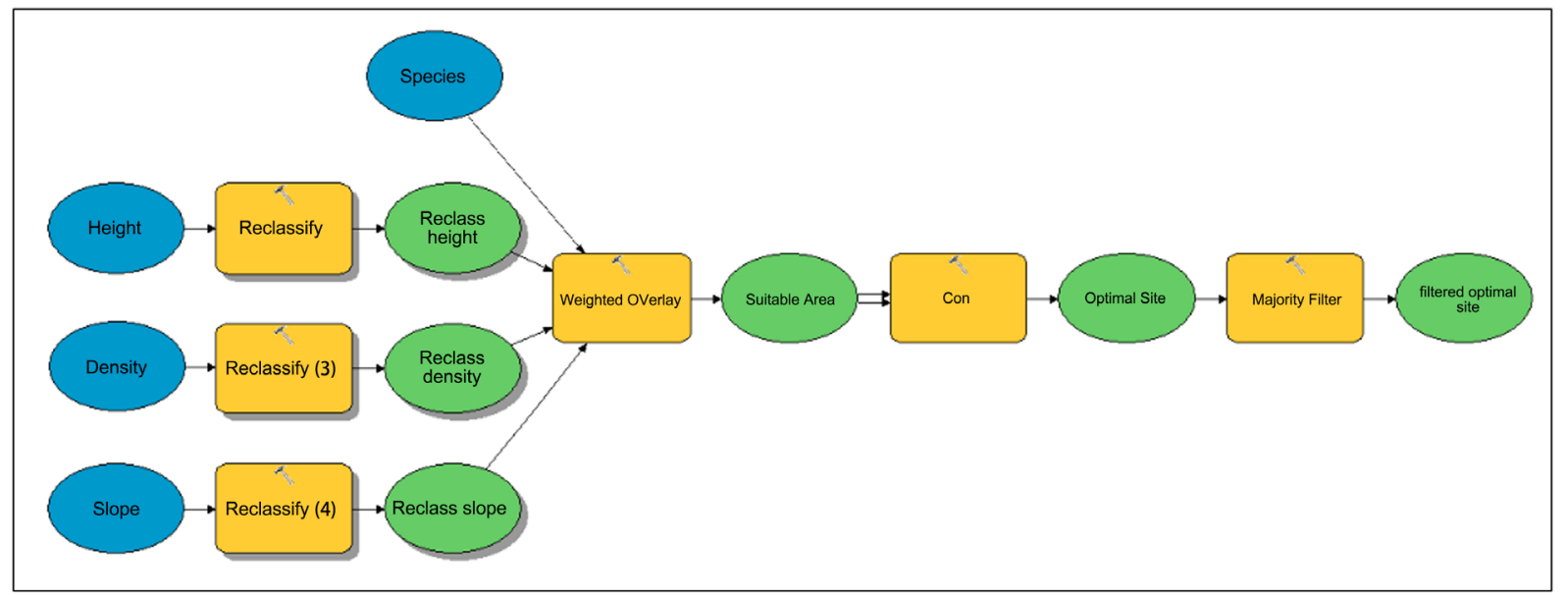

Figure 2. Spatial analysis model.

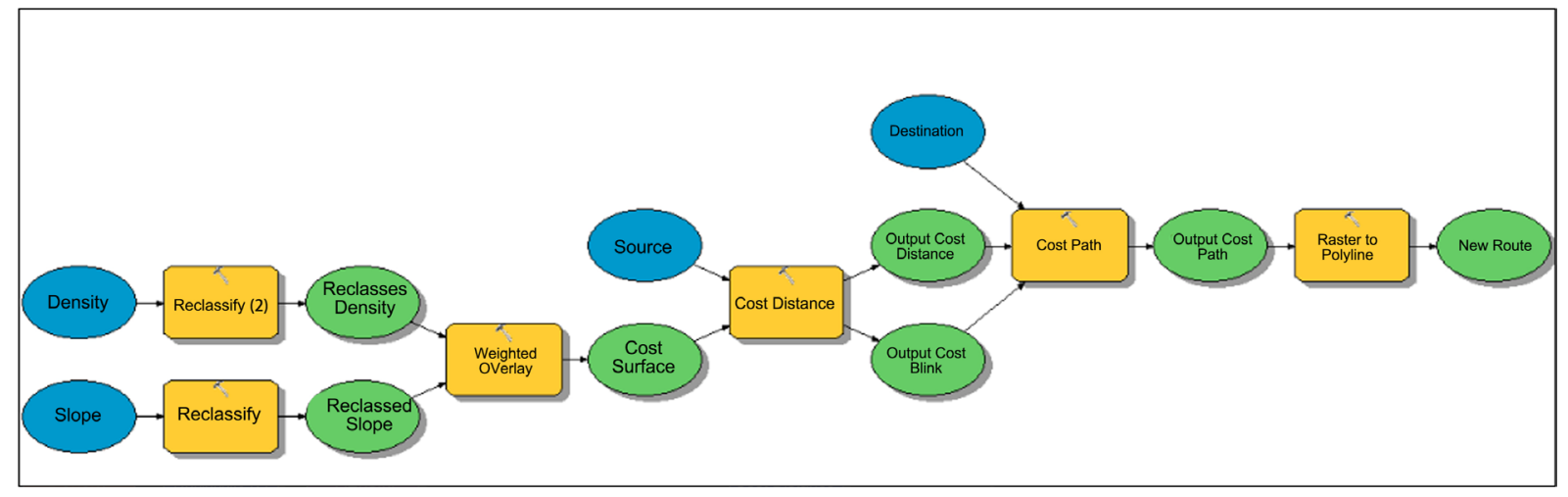

Figure 3. Accessibity routes model.

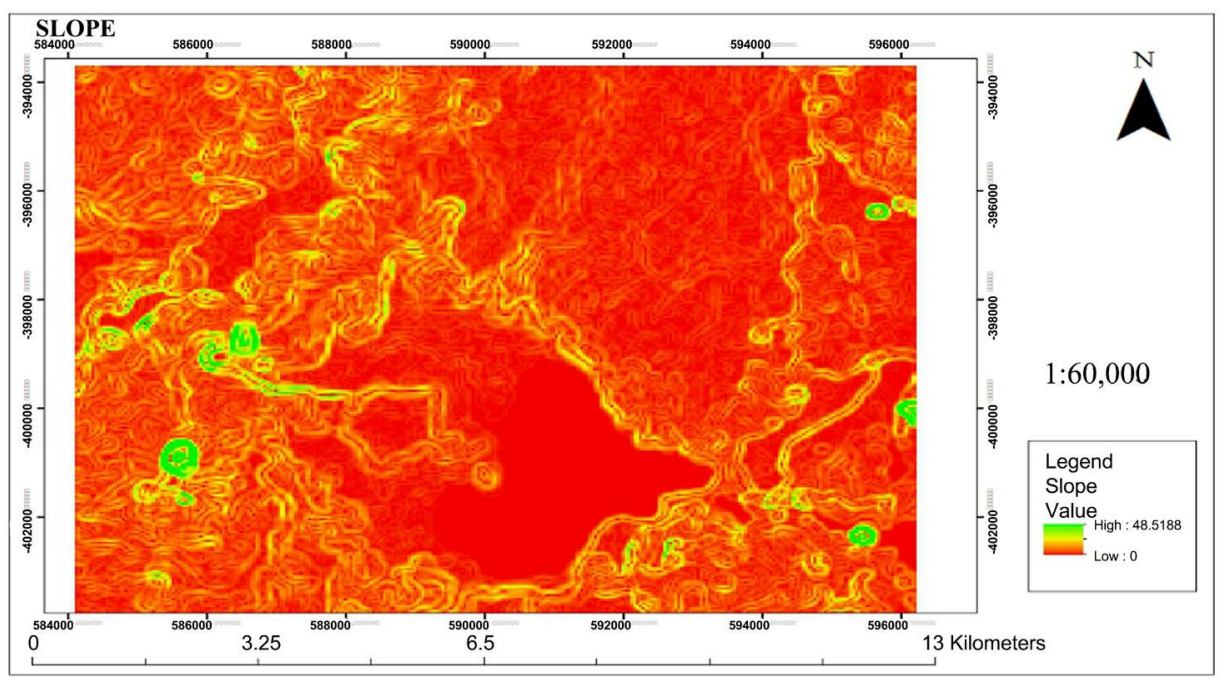

Figure 4. Slope of the area.

\subsection{Species Distribution}

Figure 5 and Figure 6 show maps and graphical distribution of mangrove species respectively. Avicennia is seen to be more dominant species in this area 


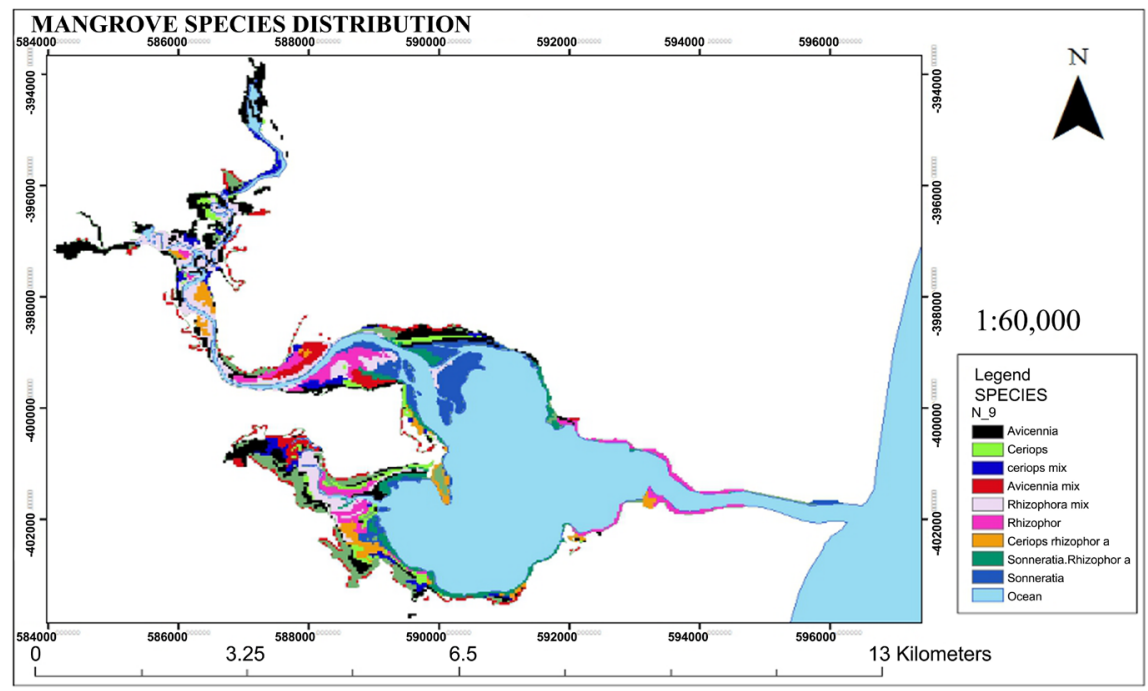

Figure 5. Species distribution map.

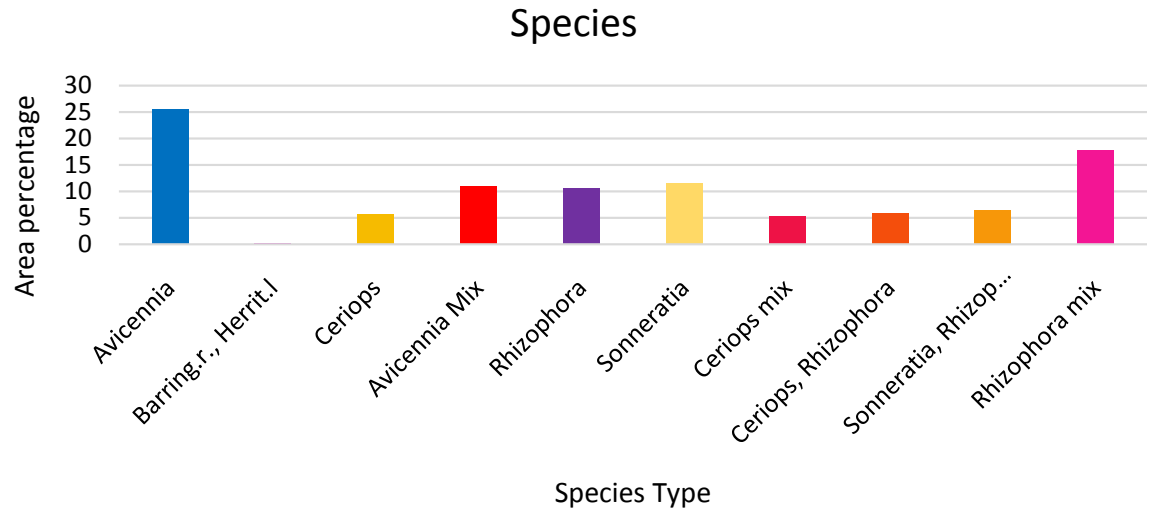

Figure 6. Species distribution graph.

followed closely by Rhiophora mix compared to other few species which occupy small areas.

\subsection{Weighted Overlay Analysis}

The weighted overlay carried out resulted into suitability maps which classified the forest into various values of suitability for harvesting and reforestation respectively. The areas with high values are the most suitable while areas, while areas with low values are the least suitable for both harvesting and reforestation. This is shown in the maps below.

Figure 7 shows suitable harvest zones whereas Figure 8 indicates suitable areas for reforestation. In the legend, 2, 3 and 4 are more suitable areas and 7 and 8 are not suitable. Similarly, 1, 2 and 3 in Figure 8 are areas that need re-forestation for better management of resource.

\subsection{Final Suitable Sites}

The map in Figure 9 shows the suitable areas to harvest the various species 


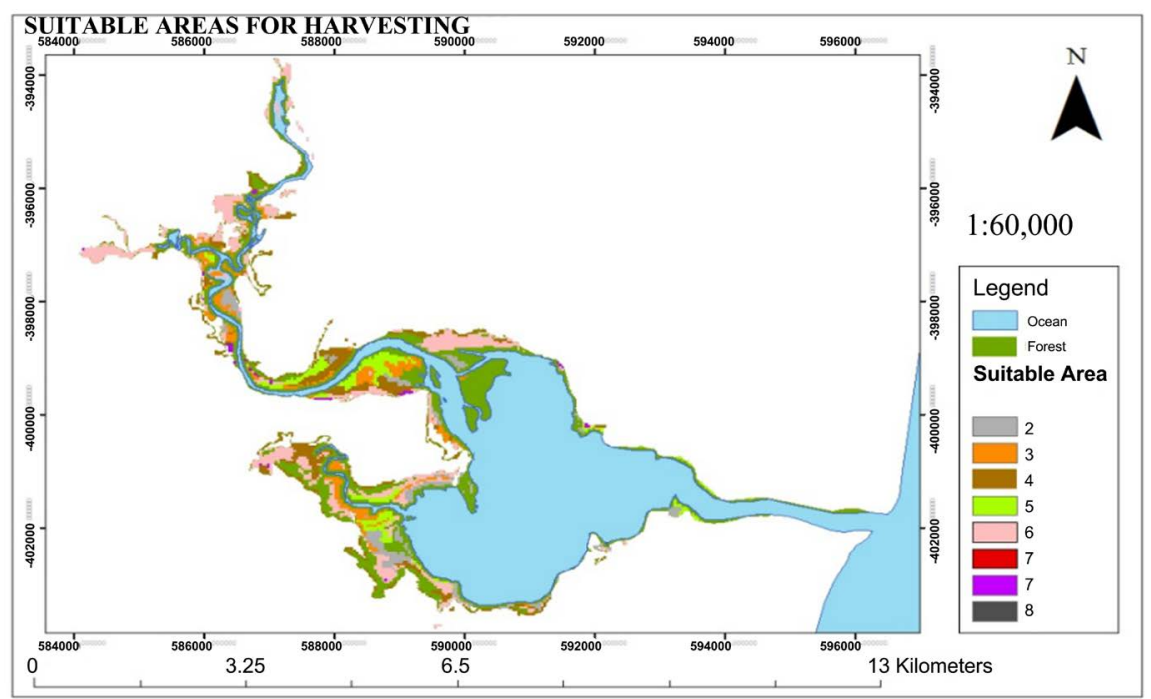

Figure 7. Suitable harvest zones.

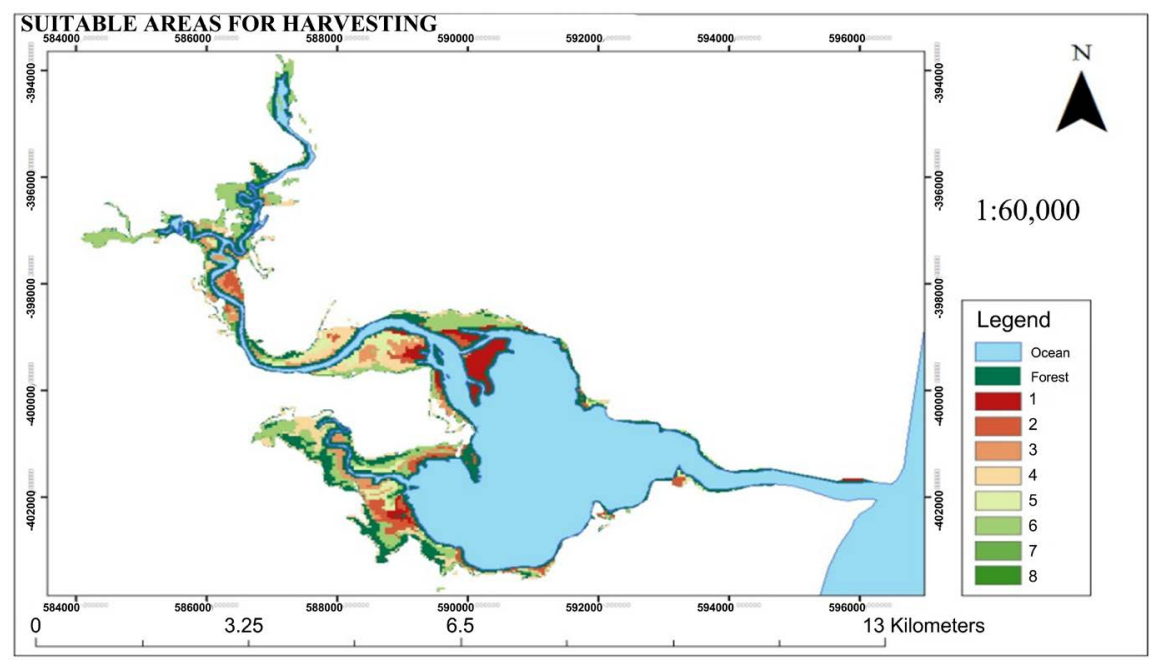

Figure 8. Suitable areas for reforestation.

within the Kilifi Creek. Each species is represented by its unique colour in the map.

The map in Figure 10 shows the suitable sites for reforestation of the various species of mangroves within the Kilifi creek.

\subsection{Final Accessibility Routes Extension}

Figure 11 shows the suitable extension of the roads within the Kilifi Creek in order to expand on the road network within the mangrove forest.

\subsection{Species Area Analysis}

The suitable areas for harvesting of the various species are shown in Table 2 below.

Avicenna Marina had the highest number since it is the most dominant species 


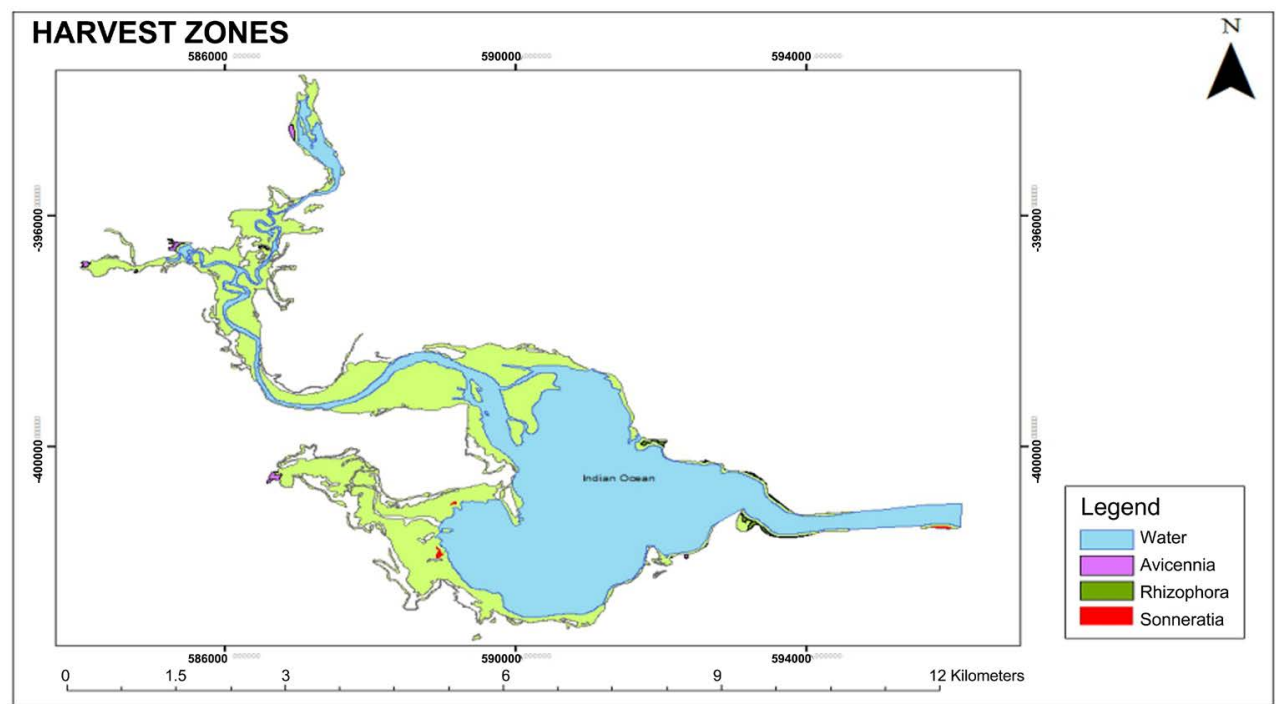

Figure 9. Final suitable harvest sites.

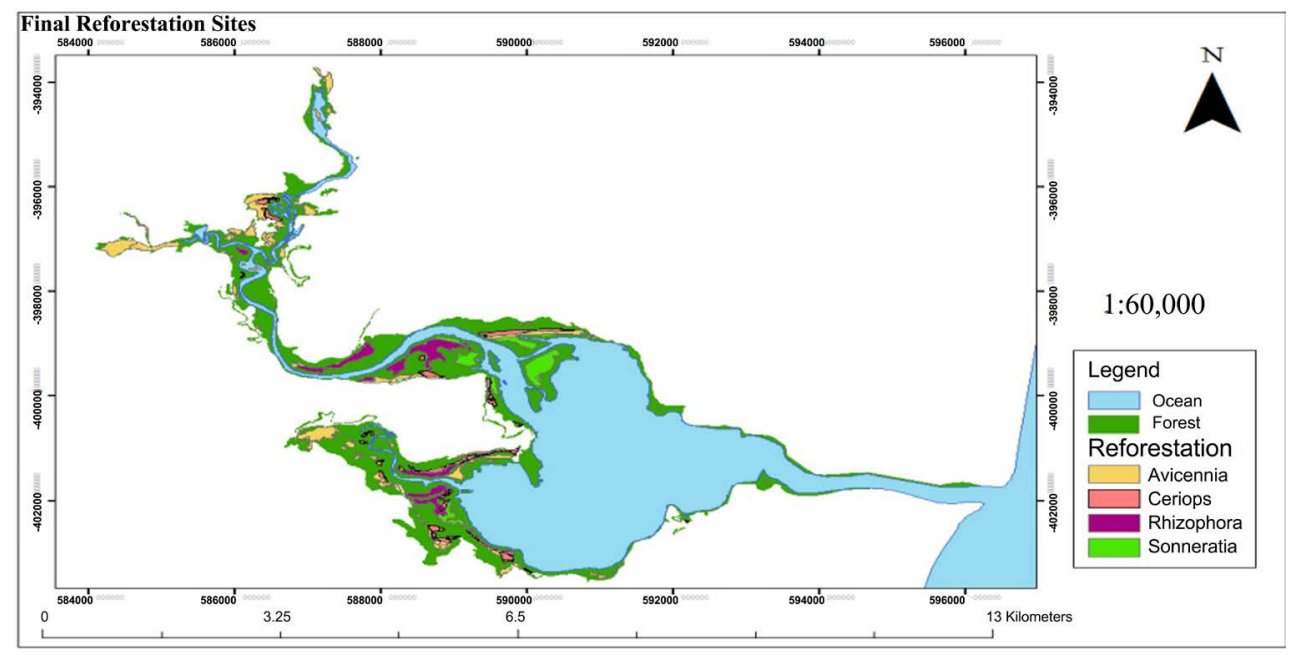

Figure 10. Final suitable areas for reforestation.

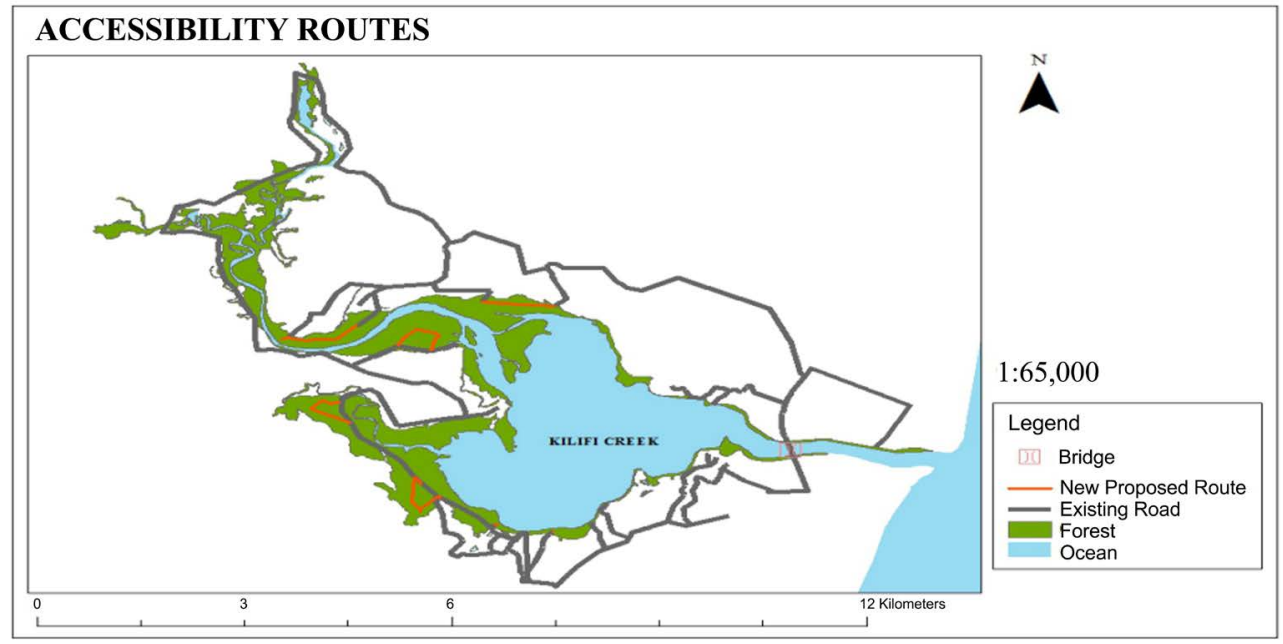

Figure 11. Route extension. 
found in the forest. The total area for reforestation of the various species is shown in the table below. The percentage is the sum of the suitable area for harvesting divided by the total area covered by the same species within the Kilifi Mangrove Forest.

Again, Avicenna marina occupied the largest area as compare to other species within the forest. The spatial distribution of the reforestation zones is shown on Figure 10 above with suitable species for each of the zones. The percentage is the sum of the suitable area for reforestation divided by the total area covered by the same species within the Kilifi Mangrove Forest (Table 3).

\subsection{Discussions}

The objectives of this research study were successfully achieved as suitable areas for harvesting and reforestation, together with route extensions were proposed with the help of geospatial technologies. The distribution of the two species which are on demand, that is Rhizophora mucronata and Ceriops tagal is 705 acres which represents the $17 \%$ of the total Kilifi Creek Mangroves as shown in Figure 6. The most dominant species in the forest is Avicenna Marina which had a percentage stand of 25.6\% (Figure 6). The less dominant species Lumnitzera racemosa and Heritiera littoralis had a stand of $0.10 \%$ which were restricted for harvesting in the analysis, they need to be protected so as to prevent its extinction in the forest which will affect the biodiversity and richness of the forest. Density and heights of the mangroves were also considered so as to prevent having bare grounds and harvesting of immature trees and encourage reforestation on the bare grounds so as to protect the forest and help in preventing soil erosion. The final suitable area for harvesting after carrying out conditional and majority filter was 394 acres which is $9 \%$ of the total forest area as shown in Table 2. Avicenna Marina had the highest number since it is the most dominant specie found in the forest. The total most suitable area for reforestation is 1151 which is $27 \%$ of the total Kilifi Mangrove Forest (Table 3).

Table 2. Area of suitable species for harvest.

\begin{tabular}{ccc}
\hline Species Type & Area (acreage) & Percentage \\
\hline Avicenna marina & 368 & 8 \\
Ceriops tagal & 12 & 0.2 \\
Rhizophora mucronata & 14 & 0.3 \\
\hline
\end{tabular}

Table 3. Area of suitable species for reforestation.

\begin{tabular}{ccc}
\hline Species type & Area (acreage) & Percentage \\
\hline Avicenna marina & 492 & 11 \\
Ceriops tagal & 191 & 4 \\
Rhizophora mucronata & 269 & 7 \\
Sonneratia & 199 & 5 \\
\hline
\end{tabular}


The total area of the road extension was $6123 \mathrm{~m}$ long after carrying out the cost surface and cost path analysis. The route consideration was where slope was relatively flat and where forest density was low so as to reduce the cost of construction of the route and also to ensure protection of the forest as minimum number of trees is to be displaced to other suitable areas.

\section{Conclusion and Recommendations}

\subsection{Conclusion}

The geospatial technologies not only allow integration of the various factors but also assist in protecting the environment, ensuring the environmental factors which are considered by setting constraints in the analysis and excluding some areas. From the research study, the most dominant species in the forest is $A v i-$ cenna marina covering $25.6 \%$ of the forest. The less dominant species were Lumnitzera racemosa and Heritiera littoralis covered $0.10 \%$ of forest area which was restricted for harvesting so as to prevent its extinction. Density and heights of the mangroves were considered for reforestation and soil conservation. Suitable area for harvesting after carrying out conditional and majority filter was 394 acres which are $9 \%$ of the total forest coverage. The total area most suitable for reforestation was found to be 1151 acres which are $27 \%$ of the total Kilifi Mangrove Forest. Buffering of $30 \mathrm{~m}$ of the shoreline was done to safeguard the shoreline from erosion and to protect the breeding grounds of the aquatic animals. The buffer zone was excluded from the analysis and the less dominant species such as herring and Lumnitzera were restricted in the analysis. This can benefit the forest managers by being aware of what area on the ground is suitable for harvesting and raising alarm for necessary restoration where density is low. This can benefit not only the forest managers but also the environmentalists as they will be assured of sustainable utilization of the limited mangrove forest resources. The forest users with harvesting licenses will also be able to identify suitable zones fast and efficiently for their various needs and uses.

\subsection{Recommendations}

Geospatial technologies together with high resolution images and lidar data could be acquired in order to facilitate in fast updating of the forest data. The high-resolution images could be used to discriminate the various species distribution. The lidar data can be used to facilitate determining the tree heights and the forest densities. This could assist in also creating baseline data which could be used for future monitoring and change detection processes. The ground data can then be used for ground-truthing purposes. The on-going efforts to restore the degraded mangroves should continue and the public should be encouraged to participate so as to create awareness and reduce the number of illegal harvesting that takes place mainly by the local communities. This will also help in achieving the Kenyan vision 2030 goal of having a 10\% tree cover country-wide and for environmental conservation which is derived from the Sustainable De- 
velopment Goals (SDGs)

\section{Acknowledgements}

We thank the department of Geomatic Engineering and Geospatial Information Systems for allowing us to work on this research. The support in terms of time, software and literature is highly appreciated. Special thanks to organizations who provided data for this kind of work.

\section{Conflicts of Interest}

The authors declare no conflicts of interest regarding the publication of this paper.

\section{References}

Baral, H. (2004). Applications of GIS in Community-Based Forest Management in Australia (and Nepal). Masters Research Thesis, Melbourne: University of Melbourne.

Baskent, E. Z., \& Jordan, G. A. (1996). Designing Forest Management to Control Spatial Structure of Landscapes. Landscape and Urban Planning, 34, 55-74. https://doi.org/10.1016/0169-2046(95)00200-6

Bosire, J. O., Dahdouh-Guebas, F., Kairo, J. G., \& Koedam, N. (2003). Colonization of Non-Planted Mangrove Species into Restored Mangrove Stands in Gazi Bay, Kenya. Aquatic Botany, 76, 267-279.

Bosire, J. O., Dahdouh-Guebas, F., Walton, M., Crona, B. I., Lewis, R. R., Field, C., Koedam, N. et al. (2008). Functionality of Restored Mangroves: A Review. Aquatic Botany, 89, 251-259. https://doi.org/10.1016/j.aquabot.2008.03.010

Gupta, M., Khare, A., \& Pathak, S. (2012). Role of Remote Sensing and GIS in Forest. International Journal of Computer Science and Informatics, 29.

Herrington, L., \& Koten, D. E. (1988). A GIS Based Decision Support System for Forest Management. Proceedings of Accessing the World GIS/LIS'88, 2, 825-831.

Kairo, J. G., Dahdouh-Guebas, F., Gwada, P. O., Ochieng, C., \& Koedam, N. (2002). Regeneration Status of Mangrove Forests in Mida Creek, Kenya: A Compromised or Secured Future? AMBIO: A Journal of the Human Environment, 31, 562-568. https://doi.org/10.1579/0044-7447-31.7.562

Marušák, R., Kašpar, J., \& Vopěnka, P. (2015). Decision Support Systems (DSS) Optimal-A Case Study from the Czech Republic. Forests, 6, 163-182. https://doi.org/10.3390/f6010163

Moore, T. G. E., \& Lockwood, C. G. (1990). The HSG wood Supply Model: Description and User's Manual (No. PI-X-98).

Pecora, G., Todaro, L., \& Moretti, N. (2014). Optimization of Timber Harvesting Using GIS-Based System. Proceeding of Second International Congress of Silviculture, 1, 892-895.

Sigana, D. O., Mavuti, K. M., \& Ruwa, R. K. (2009). Fish Species Composition and Distribution in Kilifi Creek (vol. 20, pp. 15-27). Mombasa: African Studies Centre. 


\section{Nomenclature}

AHP (Analytical Hierarchy Process), DEM (Digital Elevation Model), KFS (Kenya Forest Service), KMFRI (Kenya Marine \& Fisheries Research Institute), GIS (Geographical Information Systems), HSG (Harvest Schedule Generator) and USGS (United States Geological Survey. 